\title{
STATUS AND DISTRIBUTION OF THE GANGETIC DOLPHIN, PLATANISTA GANGETICA GANGETICA (ROXBURGH, 1801) IN RIVER BURIGANGA DURING 2003-2004 AND ITS CONSERVATION
}

\author{
Shayer Mahmood Ibney Alam* and Noor Jahan Sarker ${ }^{1}$ \\ Department of Zoology, Jagannath University, Dhaka 1100, Bangladesh
}

\begin{abstract}
Studies on the population status, distribution and conservation issues of the Gangetic dolphin Platanista gangetica gangetica were undertaken in the river Buriganga from November 2003 to November 2004. A total of 29 sightings with the highest of five sightings and a best-high-low estimate of 9-11-7 individuals were recorded in November 2004, while in the months of August and October no dolphin was observed. The mean density was 0.25 dolphin $/ \mathrm{km}$ and the highest encounter rate was 0.29 sightings $/ \mathrm{km}$. Of the total sightings, $41.38 \%$ were in the groups of more than one individuals. Of the observed dolphins, $71.43 \%$ were adults, $16.66 \%$ maturing and $11.9 \%$ young. The dolphins were found in 15 locations with both single as well as multiple sightings. Main threat to the dolphins was found to be pollution followed by traffic load and dredging activities.
\end{abstract}

Key words: Platanista gangetica gangetica, Buriganga river, status, distribution, conservation.

\section{INTRODUCTION}

The Gangetic dolphin, Platanista gangetica gangetica (Roxburgh, 1801), locally known as 'Shushuk' or 'Shishu', is one of the three species of true river dolphins of the world, that inhabits the Ganges, Brahmaputra, Meghna, Karnaphuli and Sangu rivers and their tributaries, in India, Bangladesh, Nepal and Bhutan (Mohan 1989, Perrin et al. 1989, Smith et al. 2003, Smith and Smith 1998, Smith et al. 2010). This species is classified as an endangered species in Bangladesh and is placed in the Third Schedule of Bangladesh Wildlife (Preservation) (Amendment) Act, 1974 (IUCN Bangladesh 2000). This species is on appendix 1 of the CITES and is also listed in appendix II of CMS. The Gangetic dolphins are threatened in the country from the effects of dams, large embankment schemes, dredging, fisheries by catch, directed hunting and water pollution (Smith et al. 1998). Throughout its range, the species is suffering from population decline from 5000 individuals in 1982 to fewer than 2000 in 1997 and probably in thousand in 2003 (Jones 1982, Mohan et al. 1997, Reeves et al. 2003). In Bangladesh, no population estimate for the species is available except a few discrete ones (Kasuya and Haque 1972, Haque 1976, Jones 1982, Smith et al. 1998, Smith et al. 2001, Smith et al. 2003).

*Author for correspondence. E-mail: shayermia@hotmail.com; ${ }^{1}$ Department of Zoology, University of Dhaka, Dhaka 1000, Bangladesh 
The Buriganga can be considered as the most polluted river in Bangladesh with huge industrial and household discharges, and encroachments (IWM 2004). Smith et al. (1998) conducted a short visit to the river to survey the status of the dolphins, where they observed only one group of two to three individuals. To assess the population size, distributional pattern and conservation concerns of the dolphins in the River Buriganga, the present study was conducted between November 2003 and November 2004.

\section{MATERIAL AND METHODS}

Study area: From the description of IWM (2004) and Rahman and Rana (1995), the Buriganga, having a length of only $17 \mathrm{~km}$, is one of the most important rivers in Bangladesh. It flows through the southwest of Dhaka city and meets the river Turag near Mirpur and Dhaleswari at Hariharpara. The average width of the river around Dhaka city is nearly $500 \mathrm{~m}$ and the total area is estimated to be $3.4 \mathrm{~km}^{2}$, i.e. 340 hectare. Generally, the flow of the Buriganga is non-tidal during wet season and tidal in dry season. However, the flow in the Buriganga becomes tidal in wet season when backwater effect is strong and upstream flow is small (IWM 2004). Buriganga is not an isolated river as Balu, Dhaleshwari, Kaliganga, Karnatali, Lakhya, Tongi khal and Turag River are hydraulically connected with Buriganga and influence its flow.

During the last two decades, the river has turned up as the most polluted river in the country due to the release of tremendous amount of domestic and industrial pollutants (IWM 2004). The tannery industries in the Hazaribag area, Tongi, Fatulla and Tejgaon industrial areas directly or indirectly drains waste into Buriganga. Numerous industries on the bank not only directly discharge harmful wastes into the river, but also encroach it. This has changed the water quality to such a degree that sustainability of the aquatic ecosystem is questionable, especially in the dry season. Due to pollution, fish production in Buriganga has been reduced to an alarming level (IWM 2004, Alam 2008, Ali 2008, Ahmad et al. 2010, Arias-Barreiro et al. 2010).

Data collection: Both primary (direct observation) and secondary data (from journals, books and different organizations as IWM) were collected on the population status, distribution and conservation issues of the Ganges River Dolphin in the Buriganga. Observations were made by moving along the river using engine boats (trawler), at least once a month from November 2003 to November 2004 (13 months), except for the month of July 2004 due to flood. The whole length of the Buriganga used to be covered on the same day. The average speed of the boats was five $\mathrm{km} /$ hour and the heights for observation ranged from 1.8 to 2.5 meters over water level. Observations were usually made 
between seven and nine am. The observation team consisted of two to three members.

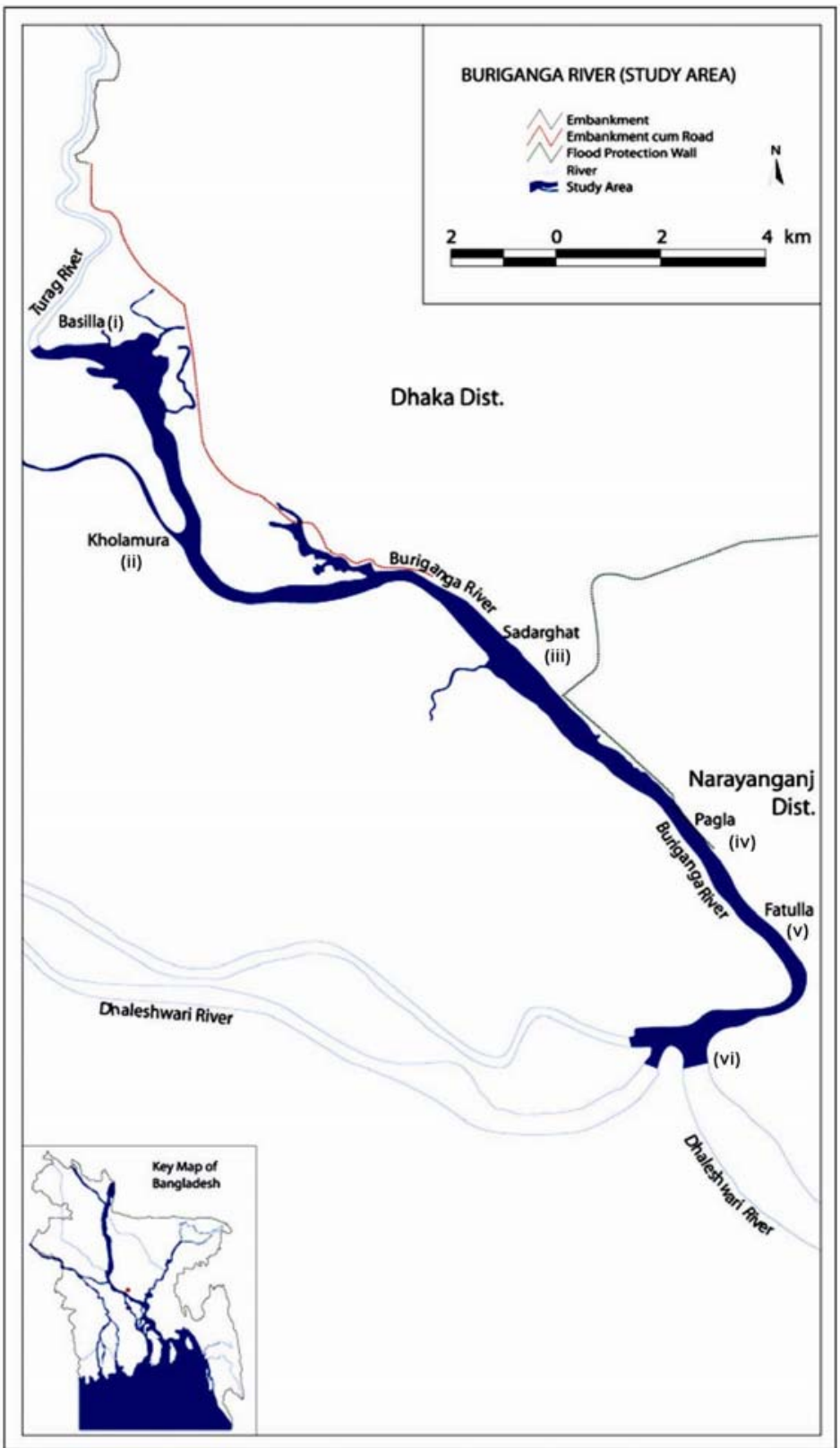

Fig. 1. Map of Buriganga River (dark area). Coordinates for different locations are (in WGS84 format): i) Basilla 23.744298, 90.346327; ii) Kholamura 23.717426, 90.359545; iii) Sadarghat 23.704595, 90.408951; iv) Pagla 23.675356, 90.442425; v) Fatullah 23.642194, 90.470631 and vi) Junction between Buriganga and Dhaleshwari river 23.627142, 90.450954 
The dolphins were located when surfacing. Binoculars were used to identify the dolphins and to trace their exact locations. Once a dolphin or a group was sighted, the numbers of dolphins were recorded with a best-high-low estimate of group size. A dolphin group was defined as any cluster of dolphins observed in apparent association, but not necessarily engaged in the same activity. High and low estimates were used to reflect the confidence in the accuracy of the best estimate. The low estimate was considered the minimum and the high was the maximum count. Distinctive physical characteristics of individual animal (e.g. body size, colour, scarring, length of the rostrum and height of the melon) and location and direction of surfacing relative to river bank features and other animals were taken into account in making group size estimates. Encounter rates (sightings per $100 \mathrm{~km}$ ) for each visit were calculated by dividing the sightings (events) by the total distance surveyed and densities (number of dolphins per linear river kilometer) by dividing the sum of best estimates for all sightings by the total distance surveyed (Smith and Reeves 2000, Smith et al. 2001).

People living near the river, specially the boatmen and the fishermen, were interviewed and asked for information about sightings of dolphins, propeller collision, past and present distribution, etc. They were shown pictures of the dolphins to avoid confusion. We tried to calculate the number of vehicles, both mechanized and non-mechanized, crossing through seven different points from 10.30 a.m. to 1.00 p.m. We also counted the number of standing vehicles at different points to figure out the traffic load at different times of the study period.

A pre-constructed data sheet was used to record the required data. Secondary data on water levels and water quality in different months of Buriganga River were collected. Coordinates of different areas were obtained in WGS84 format using website http://itouchmap.com/latlong.html. Statistical analyses, such as mean, standard deviation and correlation were done using MS Excel.

\section{RESULTS AND DISCUSSION}

Status: From different studies in Bangladesh, the densities of dolphins ranged from 0.09 to 1.36 individuals $/ \mathrm{km}$ (Smith et al. 2001, Smith et al. 2003). During the study, The Gangetic dolphins in Buriganga river were encountered 29 times (in total). Mean group size was $1.86(\mathrm{SD}=1.21)$ with a range of $1-5$ individuals. The maximum, in terms of sightings and individuals, was in the month of November 2004 with five sightings and a best-high-low estimate of 911-7 individuals, while the lowest being in the months of August and October 
2004 when no dolphin was observed (Fig. 2). The mean density was 0.249167 dolphin $/ \mathrm{km}(\mathrm{SD}=0.180225)$ with the highest of 0.53 dolphin $/ \mathrm{km}$, observed in the month of November 2004. The maximum encounter rate was 0.29 sighting/ $\mathrm{km}$ in the month of November 2004.

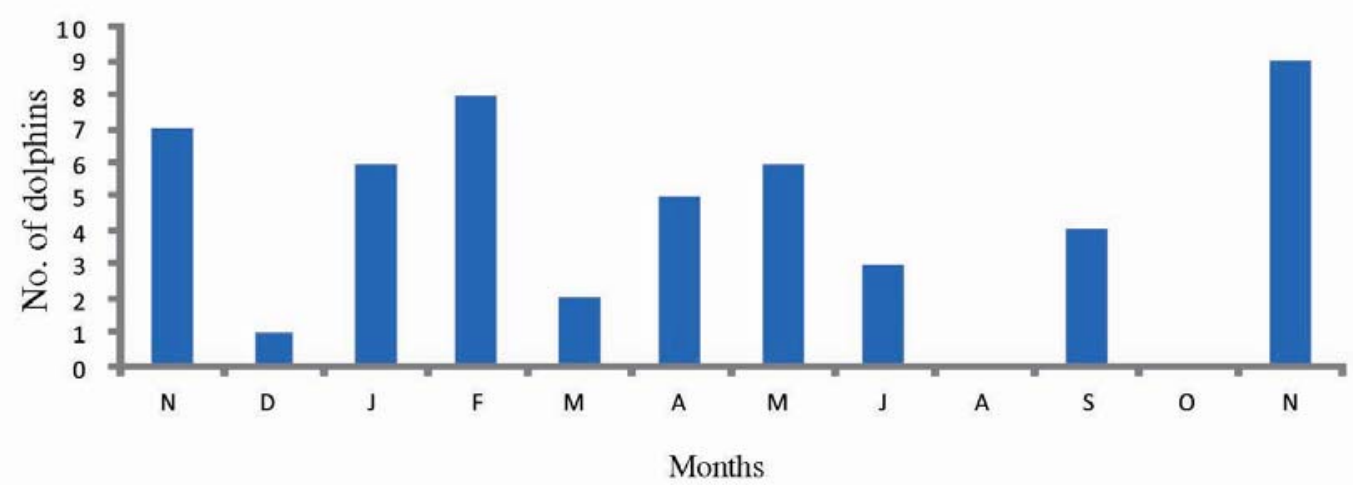

Fig.2. Month-wise estimates of dolphins in Buriganga river from November 2003 to November 2004.

Post monsoon (November to February) had the maximum mean best-highlow estimate of $6.2-7.8-5.6$ ( $\mathrm{SD}=3.11-4.08-2.60$, respectively), maximum mean group size of 2.06 individuals $(\mathrm{SD}=1.13)$, maximum mean encounter rate of 0.18 sightings $/ \mathrm{km}(\mathrm{SD}=9.66)$ and maximum mean density of 0.36 dolphin $/ \mathrm{km}$ (SD = 0.18) (Fig. 3). The marked seasonal changes in the distribution of dolphins and density over much of its range are due, at least in large part, to fluctuations in water levels. During the dry season many dolphins leave the tributaries and congregate in the main channels, only to return to the tributaries the following rainy season. (Reeves and Brownell 1989). Besides, during monsoon the water level rises considerably (Fig 4) and annual monsoon driven floods cause great variability in the dolphin's access to large part of their range. These can be the reason for low sighting in monsoon.

In February, no dolphin was observed from Madrasa ghat to Basilla. It was probably due to the heavy load from the tannery industries after Eid-ul-Azha. At that time, the water of the Buriganga appeared to be black and thick with very bad smell, starting from the Bangladesh-China Friendship Bridge 1 at Postogola to the north.

Out of the total sightings, $41.38 \%$ were found in the groups of more than one individual. Out of the total observations, $71.43 \%$ were recorded adult, $16.66 \%$ mid-aged and $11.9 \%$ young. This figure indicated a probable decline in population size for the future. However, two new born dolphins were observed in February as identified by their size, surfacing, specially pinkish skin colour. 


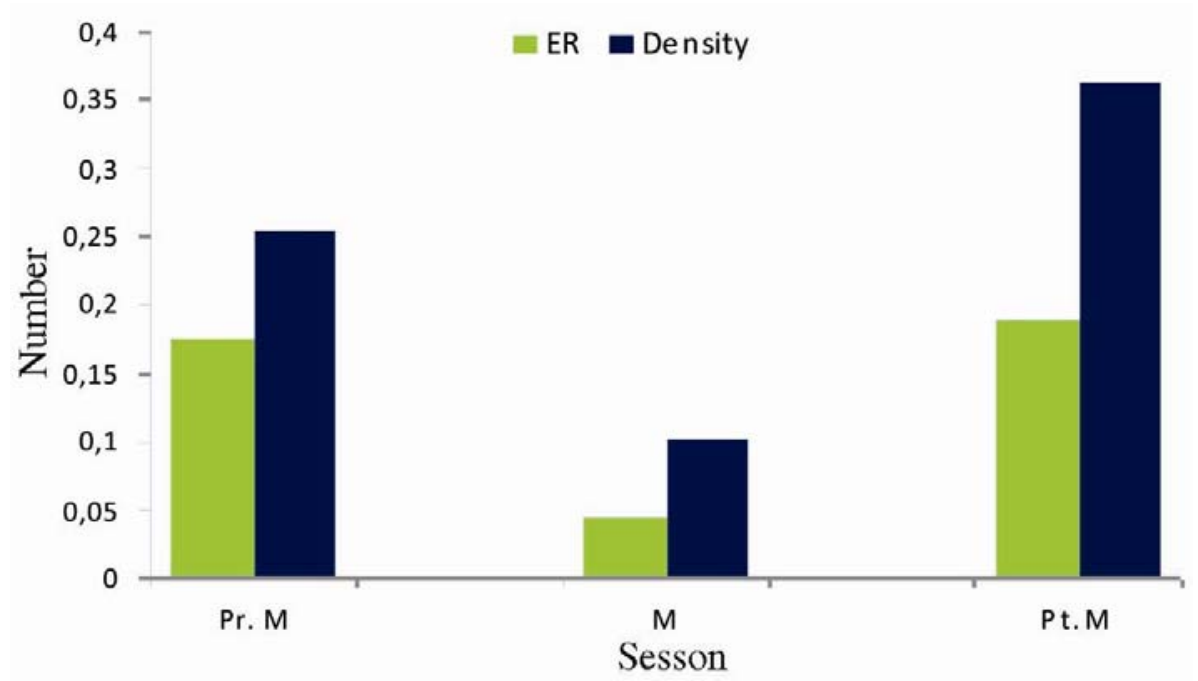

Fig. 3. Seasonal variation in encounter rate (ER) and density of dolphins in Buriganga river observed from November 2003 to November 2004. Pr. M = Pre monsoon; $M$ = Monsoon; Pt. M = Post monsoon.

Distribution: From the study, it was observed that the Gangetic dolphins were location specific. A total of 15 locations was observed with both single as well as multiple sightings (Fig. 4). It was also observed that no sighting was there between Kholamura and Pagla except only one observation (with a best estimate of 0 in Sadarghat in November 2003). Thus, the dolphins were distributed in the Buriganga river on two sites, one from Pagla to the junction between Buriganga and Dhaleswari while the other from Kholamura to Basilla. This might be due to highly polluted situation in this area. A weak negative relationship ( $r=-0.44323)$ was found between the dolphin sighting and the water level in the river. The sightings of dolphins in different seasons are given in Table 1.

Table 1. Distribution of the gangatic dolphins in different seasons in the river Buriganga.

\begin{tabular}{lll}
\hline Season & Month & Dolphin sighting site numbers \\
\hline Pre Monsoon & March to May & $1,2,3,4,7$ and 10 \\
Monsoon & June to October & 10 and 15 \\
Post Monsoon & November to February & $2,3,4,5,6,8,10,11,13,14$ and 15 \\
\hline
\end{tabular}

From the study, it can be assumed that all of the dolphins of the Buriganga are not exclusively of this river as the two main points are at or near the junctions of the other two rivers - the Junction with Dhaleswari in the south and Kholamura in the north. So, these were basically the populations utilizing 
two rivers (Buriganga and Turag or Buriganga and Dhaleswari). Besides, other sightings occurred within 4 to 5 kilometers of the junctions. Therefore, there is a great possibility of movement of these dolphins from the Buriganga to Dhaleswari and Turag on both ends, and the exact number of the dolphins in the river was thus hard to determine. Moreover, there is a big gap from Madrasa ghat to Pagla where dolphins were almost totally absent and there were variations in the number of dolphins sighted on different months that ranged from 0 to 8 on one site.

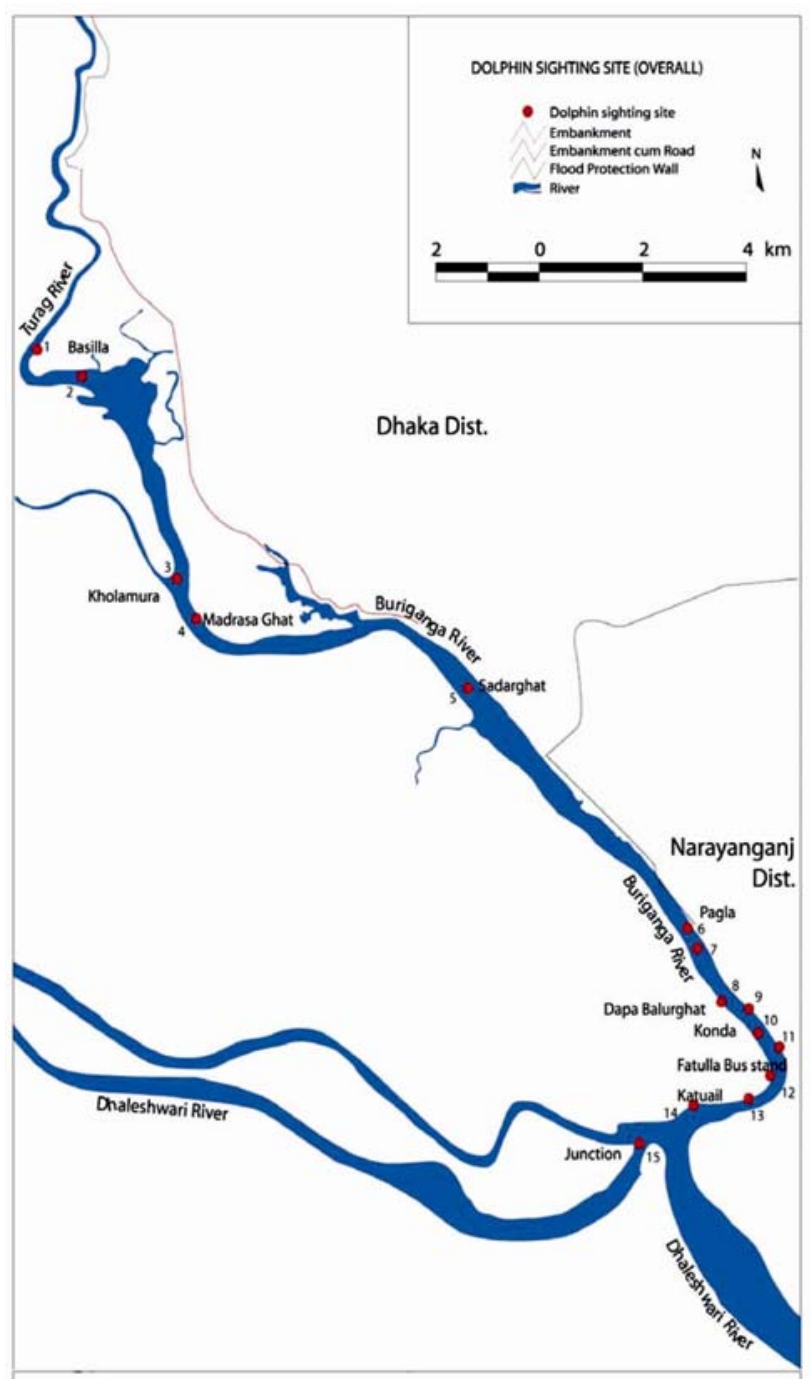

Fig. 4. Locations of dolphin sightings. A total of 15 sights have been located during the study with single as well as multiple sightings. 
Conservation issues: We assume that the main threats the Gangetic dolphin in the river Buriganga was the pollution, traffic, specially the motor vessels of different types and size and dredging activity also affected the dolphins.

One of the important water quality parameters is Dissolved Oxygen (DO) in water. It is an indication of organic pollutants present in the water body as lower values indicate highly polluted water. According to the Environment Quality Standard (EQS) of the Department of Environment (DoE), a minimum DO value of $4 \mathrm{mg} / 1$ is considered acceptable for fisheries and aquatic life (JICA 2000).

Another important parameter is Biological Oxygen Demand (BOD) that has the limiting value $10 \mathrm{mg} / 1$ as per EQS. It was observed that the DO levels from Mirpur Bridge to Pagla were far below the minimum required value of $4 \mathrm{mg} / 1$ $(0.1-1 \mathrm{mg} / 1)$ while progressing towards Dhaleswari River (5.5-7.25 mg/1) (IWM 2004). The same study also revealed that the BOD limit also exceeds the limiting value $(10 \mathrm{mg} / \mathrm{l})$ for most part of the river in March (14-16 mg/1). During the monsoon, however, the river receives sufficient flow from the upstream rivers and the water quality becomes better (DO $6.75 \mathrm{mg} / 1$ and BOD $3.5 \mathrm{mg} / 1$ ).

In another study by Shamsuzzoha (2002), it was found that except for Selenium and Zinc, concentrations of the other five heavy metals were higher than recommended concentrations for the river water to be used as drinking water. Accumulation of different heavy metals was documented for the dolphins in the Ganges River of India with high levels in the liver, except for cadmium and lead which concentrated in kidneys (Kannan et al. 1993). This phenomenon might be related to the modified physiological functioning of freshwater cetaceans (Zhou and Li 1989).

These two points set the basis for why dolphins were not recorded from Madrasa ghat to Pagla. However, Madrasa ghat and Pagla were the starting point on both side for dolphin sighting (Fig. 4). Though there was a sighting at Sadarghat, it has the best estimate of zero (0).

We found that on an average, a total of 188 vehicles crossed different points and another 1,270 vehicles remained standing that also ran through the river. During the study, two reports of dolphin collision with the propeller were recorded from interviewing people. There was also no report of accidental killing from entanglement in fishing nets during the study period. No report of deliberate killing (poaching) was found. But people took dead or hurt dolphins to use as medicines for rheumatism and to use as fish bait. Dolphins may be particularly vulnerable to vessel strikes during calving and nursing periods. The constant noise of vessel traffic might inhibit the ability of river dolphins to avoid collision with potential consequences (Smith and Smith 1998). 
Based on the above mentioned facts, we can make a few recommendations for the conservation of dolphins in the Buriganga. In this regard, most emphasis should be given on shifting harmful industries immediately from the river bank. Scientific and eco-friendly waste disposal procedures must be adopted by all industries and should be monitored by the concerned authorities regularly. Related existing laws should be enforced strictly and severe punishment including higher penalties should be charged against the polluting agencies. More water treatment plants with proper disposal plans should be constructed. Public awareness should be created on the role of dolphins in nature, pollution and its effects, environment legislations and importance of the clean Buriganga on socio-economy. School children can be educated and encouraged for the conservation of the species. Studies on the effect of pollutants like heavy metals in the tissue of dolphins (physiological and behavioral) should be conducted. Boatmen or launch drivers should be trained and motivated to avoid dolphins and fishermen should be trained to handle and release dolphin in case of any entanglement to fishing nets. Besides, the Gangetic dolphin should be declared as a flagship species in restoring the Buriganga.

Concluding remarks: The study found that the most of the threats to the Gangtic dolphins (Platanista gangetica gangetica) in the river Buriganga were anthropogenic that shaped their status and distribution within the river. The Buriganga itself is a small river of only $17 \mathrm{~km}$ and there is a gap in the distribution of these dolphins that have concentrated them on the both ends of the river. The Government has taken steps to relocate the tannery industries. But there are other industries rather than tanneries that drain pollutants directly and indirectly into the river. Moreover, increasing number of industries has increased traffic loads in the river. Such rising threats will decrease their chances of existence. As the river plays a great role in communication with the capital Dhaka, declaration of any sanctuary for the dolphins in the river is virtually impossible. So, from the scientific point of view, it will be an opportunity to observe the condition whether the population bounces back or not after the removal of the tanneries.

Acknowledgement: We would like to thank Dr. Benazir Ahmed, Professor, Department of Zoology, Chittagong University for his valuable suggestions during the study. Our special thanks to Mr. Tapas Ranjan Chakraborty and Mrs. Ismat Ara Falguni from Bangladesh Centre For Advanced Studies (BCAS), Mr. Raguib Uddin Ahmed, Ecologist and Trainer, Centre for Environment and Geographic Information Services (CEGIS), Mr. Mir Mostafa Kamal, Surface Water Modeller, Institute of Water Modelling (IWM), Director, BANSDOC and Superintending Engineer, Processing and Flood Forecasting circle, Bangladesh 
Water Development Board (BWDB) for their cooperation in getting required data and information. We would also thank Kazi Ahmed Kabir, Refat Laila Baby and Shahnoor Sabbir of Department of Zoology, University of Dhaka for their cooperation during gathering and generating data during the study. Finally, we would like to thank Dr. Haseeb Md. Irfanullah, Practical Action Bangladesh, Dr. Bodil Elamhagen, Assistant Professor, Department of Zoology, Stockholm University, Sweden and Laetitia Georgina Schmid of Stockholm University, Sweden for their comments on the manuscript.

\section{LITERATURE CITED}

AHMAD, M.K., ISLAM, S., RAHMAN, S., HAQUE, M.R. and ISLAM, M.M. 2010. Heavy Metals in Water, Sediment and Some Fishes of Buriganga River, Bangladesh. Int. J. Environ. Res. 4(2): 321-332.

ALAM, K. 2008. Cost-Benefit Analysis of Restoring Buriganga River, Bangladesh. Water Resources Development 24(4): 593-607.

ALI, M.Y., AMIN, M.N. and ALAM, K. 2008. Ecological Health Risk of Buriganga River, Dhaka, Bangladesh. Hydro Nepal. 3: 1-4.

ARIAS-BARREIRO, C.R., NISHIZAKI, H., OKUBO, K., AOYAMA, I. and MORI, I.C. 2010. Ecotoxicological characterization of tannery wastewater in Dhaka, Bangladesh. J. Environ. Biol. 31(4): 471-475.

HAQUE, A.K.M.A. 1976. Comments on the Abundance and Distribution of the Ganges susu, Platanista gangetica and the Effect of the Farrakka Barrage on its Population. ACMRR/MM/SC 132. Advisory Committee on Marine Resources Research, Scientific Consultation on Marine Mammals. FAO, Rome.

IUCN Bangladesh. 2000. Red Book of Threatened Mammals of Bangladesh. IUCN- The World Conservation Union. xii $+71 \mathrm{pp}$.

IWM. 2004. Feasibility \& Mathematical Model Study of Approaching and Investigating Strategy for Rehabilitating the Buriganga-Turag-Shitalakhya River System and Augmentation of Dry Season Flow in the Buriganga River, Feasibility Report. Bangladesh Water Development Board, Ministry of Water Resources, GoB.

JICA. 2000. Baseline Information Study of the Dhaka Combined Flood Control cum Eastern Bypass Road Project, Final Report, Bangladesh Water Development Board, Ministry of Water Resources, Government of Bangladesh.

JONES, S. 1982. The present status of the Gangetic susu, Platanista gangetica (Roxburgh), with comments on the Indus susu, P. minor Owen. In: Mammals of the Seas. F.A.O. Fish. Ser. 5(4): 97-115.

KANNAN, K., SINHA, R.K., TANABE, S., ICHIHASHI, H. and TATSUKAWA, R. 1993. Heavy metals and Organochlorine residues in Ganges River Dolphin from India. Mar. Pollut. Bull. 26(3): 159162.

KASUYA, T. and HAQUE, A.K.M.A. 1972. Some Information on the Distribution and Seasonal Movement of the Ganges Dolphin. Sci. Rep. Whales Res. Inst.Tokyo 24: 109-115.

MOHAN, R.S.L. 1989. Conservation and Management of the Ganges River Dolphin, Platanista gangetica, in india. In: Biology and conservation of the river dolphins, occasional papers of the IUCN Species Survival Commission, No. 3. (Eds., Perrin, W.F., Brownell, R.L., Zhou, K. and Liu, J.) IUCN, Gland, Switzerland. pp. 64-69. 
MOHAN, R.S.L., DEY, S.C., BAIRAGI, S.P. and ROY, S. 1997. On a survey of Ganges River dolphin Platanista gangetica of Brahmaputra River, Assam. J. Bombay Nat. Hist. Soc. 94: 483-495.

PERRIN, W.F., BROWNELL, R.L., ZHOU, K. and J. LIU ( Eds.). 1989. Biology and conservation of the river dolphins, occasional papers of the IUCN Species Survival Commission, No. 3. 180+V pp.

RAHMAN, M.R. and RANA, M.Y. 1995. Management of Buriganga River Water quality under Alternative Scenarios. Final report (RO2/95). Institute of Flood Control and Drainage Research, Bangladesh University of Engineering and Technology, Dhaka. Bangladesh.

REEVES, R.R. and BROWNELL, R.L. 1989. Susu - Platanista gangetica (Roxburgh, 1801) and Platanista minor Owen, 1853. In: Handbook of Marine Mammals (Eds., Ridgway, S.H. and Harrison, S. R.) Vol. 4: River Dolphins and the Larger Toothed Whales. Academic Pres, London, pp. 69-100.

REEVES, R.R., SMITH, B. D., CRESPO, E. and NOTARBARTOLO, D.S. 2003. Dolphins, Whales and Porpoises: 2002-2010 Conservation Action Plan for the World's Cetaceans. IUCN, Gland, Switzerland.

SHAMSUZZOHA, M. 2002. Dhaka City's Waste and Waste Management Scenario. In: Bangladesh Environment 2002. Vol 2. (Eds., Ahmed, M. F., Tanveer, S. A. and Badruzzaman). BAPA, Dhaka, Bangladesh. pp. 818-829.

SMITH, A.M. and SMITH, B.D. 1998. Review of Status and Threats to River Cetaceans and Recommendations for their Conservation. Environ. Rev. 6: 189-206.

SMITH, B.D., HAQUE, A.K.M.A., HOSSAIN, M.S. and KHAN, A. 1998. River Dolphins in Bangladesh; Conservation and the Effects of Water Development. Environ. Man. 22(3): 323-335.

SMITH, B.D. and REEVES, R.R. 2000. Survey Methods for Population Assessment of Asian River Dolphins. In: Biology and Conservation of Freshwater Cetaceans in Asia, Occasional Paper of the IUCN Species Survival Commission, No. 23. (Eds., Reeves, R. R., Smith, B. D. and Kasuya, T.), IUCN, Gland, Switzerland, pp. 97-115.

SMITH, B.D., AHMED, B., ALI, M. E. and BRAULIK, G. 2001. Status of Ganges River Dolphin or Shushuk Platanista gangetica in Kaptai Lake and Southern Rivers of Bangladesh. Oryx 35(1): 61-72.

SMITH, B.D., AHMED, B. and MANSUR, R. 2003. Report of the Seminar on the Conservation of River Dolphins in the Sundarbans Delta and Sangu River of Bangladesh.16 October 2003, Islamic Development Bank, Dhaka.

SMITH, B. D., DIYAN, M. A. A., MANSUR, R. M., MANSUR, E. F. and AHMED, B. 2010. Identification and channel characteristics of cetacean hotspots in waterways of the eastern Sundarbans mangrove forest, Bangladesh. Oryx 44(2): 241-247.

ZHOU, K. and LI, Y. 1989. Status and aspects of the ecology and behaviour of the Baiji, Lipotes vexillifer in the lower Yangtze River. In: Biology and conservation of the river dolphins, occasional papers of the IUCN Species Survival Commission, No. 3. (Eds., Perrin, W.F., Brownell, R.L., Zhou, K. and Liu, J.) IUCN, Gland, Switzerland, pp. 86-91. 